\title{
AN IMPROVED TECHNIQUE OF INTRA-OPERATIVE BONE SCANNING
}

\author{
E. P. SZYPRYT, J. G. HARDY, C. L. COLTON \\ From the Queen's Medical Centre, Nottingham
}

\begin{abstract}
Radiopharmaceuticals have been successfully used to detect occult neoplasms and infective lesions. Bone scans using ${ }^{99 \mathrm{~m}} \mathrm{Tc}$-labelled methylene diphosphonate located osteoid osteomas accurately in a series of 30 symptomatic patients. A portable radiation detector system has been designed to help intra-operative localisation and facilitate complete excision of the lesions with minimal damage to normal tissue. A sodium iodide detector with a fibre-optic link was used at first, but a cadmium telluride system has provided a more durable, reliable and sensitive sterilisable probe.
\end{abstract}

Radiopharmaceutical compounds have been used with great success to aid the detection of occult bony neoplasms and infections. Following the introduction by Subramanian and McAfee in 1971 of phosphate compounds labelled with technetium-99m, methylene diphosphonate (MDP) labelled with this isotope has become well-established for the imaging of bone tumours and infections. Its high bone uptake and rapid blood clearance make it ideally suited (Duthie and Bentley 1983, pp 20-1).

Biopsy of pathological tissue is often needed and tomographic radiography and computerised tomography of areas of increased radionuclide concentration (Gamba et al. 1984) can help in the precise localisation of such lesions. But, even with external marking devices, the sites are often difficult to identify accurately at operation (Harvey and Lancaster 1981), especially when the macroscopic appearance of the bone is normal.

A good example of this difficulty is that encountered during the excision of an osteoid osteoma. This benign lesion, first described by Jaffe (1935), can occur in any bone, but most are seen in the metaphyseal region of long bones and in the axial skeleton (Jackson, Reckling and Mantz 1977; Swee, McLeod and Beabout 1979; Rinsky et al. 1980). Fortunately, osteoid osteomas concentrate radiopharmaceuticals (Mallens, Pauwels and Tetteroo 1977; Lisbona and Rosenthall 1979; Smith and Gilday 1980) allowing localisation by scintigraphy when they are not readily apparent on standard radiographs. Osteoid osteomas induce much more reactive bone

E.P. Szypryt, FRCS, Spinal Research Fellow

J.G. Hardy, PhD, Physicist

C.L. Colton. FRCS, FRCS Ed (Orth), Orthopaedic Consultant

Department of Orthopaedics, University Hospital, Queen's Medical Centre. Nottingham NG7 2UH, England.

Requests for reprints should be sent to Mr C.L. Colton.

(c) 1986 British Editorial Society of Bone and Joint Surgery $0301-620 \mathrm{X} / 86 / 4113 \$ 2.00$ formation in cortical bone than in cancellous bone; the latter type are more difficult to localise (Golding 1954; Swee et al. 1979; Clark, Ozonoff and Drennan 1981; Gamba, Apple and Martinez 1983; Gamba et al. 1984).

It is widely accepted that complete removal of the central nidus will effect a cure, although occasional recurrences have been recorded (Dunlop, Morton and Elliott 1970). The lesion may also be multicentric (Glynn and Lichtenstein 1973). It is not uncommon for patients to undergo several excision operations because of incomplete resections (Jackson et al. 1977). Standard intra-operative radiographs may give no clue to exact location and may be difficult to interpret, especially in the axial skeleton. More accurate pre-operative localisation using computerised tomography (Gamba et al. 1983, 1984) may be of little help unless the bone has an abnormal external appearance (Broderick, Resnick and Usselman 1980). In such difficult cases excessive amounts of healthy tissue may be excised in the search for the all-important nidus.

Intra-operative scintigraphy was developed to help eliminate these problems, since false-negative scintigrams have never been reported in histologically confirmed osteoid osteoma (Lisbona and Rosenthall 1979; Smith and Gilday 1980). Rinsky et al. (1980) were the first to describe the use of a mobile gamma-camera during an operation. Harvey and Lancaster (1981) described a sterilisable probe using a sodium iodide detector with a fibre-optic link and reported that a major disadvantage of the system was the loss of optical energy. This resulted from reflection, packing losses due to space between fibres and spectral transmission losses within the glass fibre cores. Colton and Hardy (1983) described reduced reliability of a similar probe after long-term use because of the hygroscopic properties of the sodium iodide crystal and deterioration of the fibre-optic cable. Because of these problems a new probe based on a cadmium telluride detector system has been developed. 


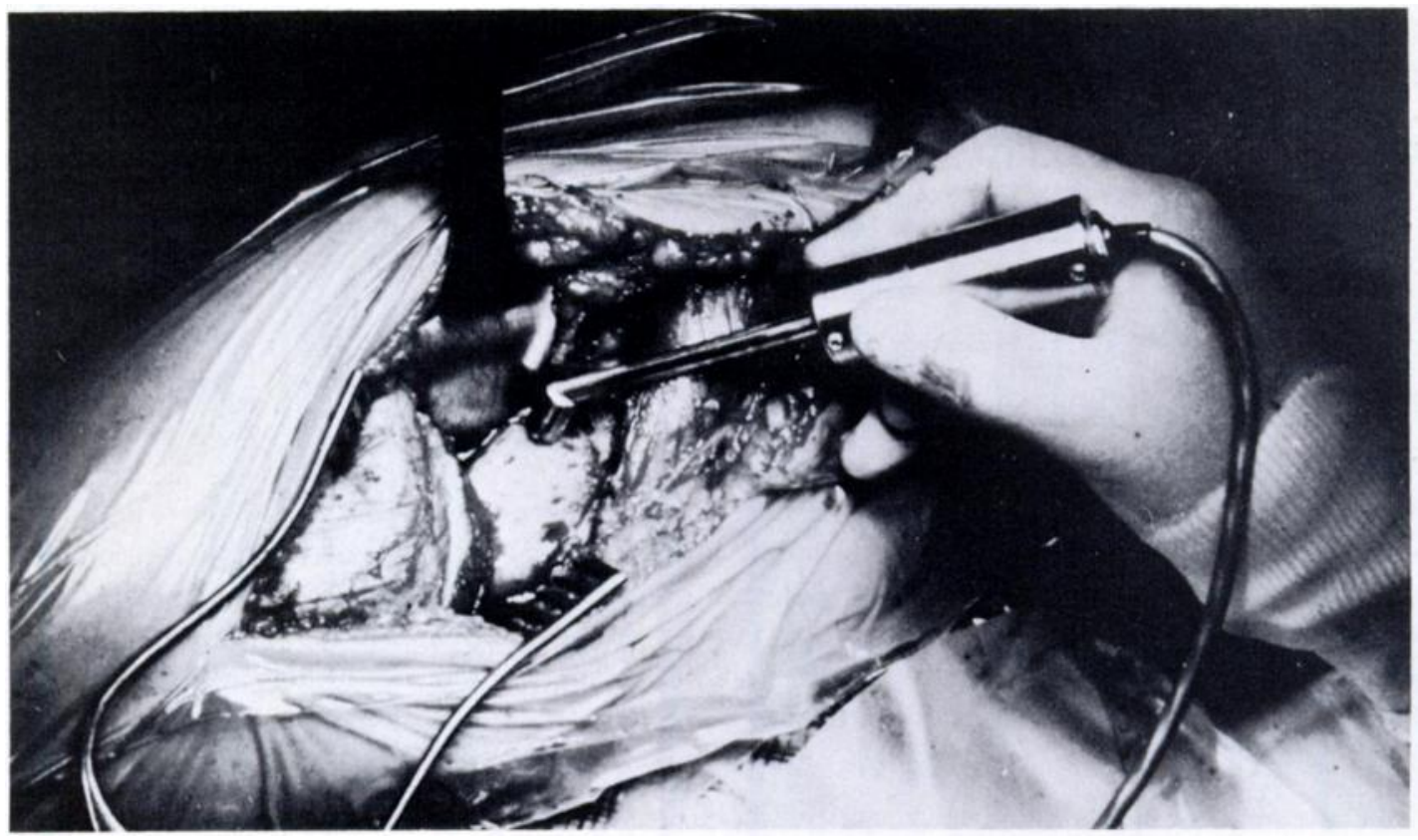

Fig. 1

The cadmium telluride probe in use during an operation

\section{MATERIALS AND METHODS}

The new, fully portable radiation probe is a cadmium telluride crystal, mounted in a collimator $10 \mathrm{~mm}$ in diameter with a $3 \mathrm{~mm}$ diameter window. The detector is mounted on a handle $14 \mathrm{~cm}$ in length (Fig. 1), and is connected by a $1.8 \mathrm{~m}$ cable to a compact scalerratemeter powered by rechargeable batteries. The equipment was manufactured by Radiation Monitoring Devices, Watertown, Massachusetts, USA. This cadmium telluride probe has been used during surgical exploration of 20 patients to locate bony lesions which had shown discrete increased uptake of $99 \mathrm{~m} \mathrm{Tc}-\mathrm{MDP}$ during pre-operative scintigraphy (Table I).

About three hours before operation each patient was injected with $15 \mathrm{mCi}$ of ${ }^{99 \mathrm{~m}} \mathrm{Tc}-\mathrm{MDP}$, a reduced dose being used for children. After adequate exposure of the bone, the head of the radiation detector was moved along its surface to identify the point of highest emission of gamma rays (Fig. 1). The count rate from bone at a distance from the lesion gave a background reading, allowing a target-to-background ratio to be calculated. After removal of the lesion the resultant cavity was scanned to ensure that readings had returned to background levels. Since about $60 \%$ of the dose appears in the urine within three hours (Subramanian and McAfee 1971) care was taken to reduce the background count rate for a lesion in the pelvic region by ensuring that the bladder was empty before operation. In addition, surgical approaches were designed to allow directional use of the probe away from areas likely to produce high background readings.
Table I. Details of 20 operations in which the cadmium telluride probe was used

\begin{tabular}{llllll}
\hline Diagnosis & $\begin{array}{l}\text { Number of } \\
\text { cases }\end{array}$ & $\begin{array}{l}\text { Sex } \\
\mathbf{M}\end{array}$ & $\begin{array}{l}\text { Age } \\
\text { (years) }\end{array}$ & $\begin{array}{l}\text { T/B } \\
\text { ratio }\end{array}$ \\
\hline Osteoid osteoma & 10 & 6 & 4 & 3 to 33 & 2.5 to 12.0 \\
Infarcted bone & 2 & 1 & 1 & 20 and 49 & 2.0 and 4.0 \\
Hamartoma & 1 & 1 & - & 16 & 4.0 \\
Ectopic osteochondromatosis & 1 & - & 1 & 59 & 4.0 \\
Osteoblastoma & 1 & 1 & -28 & 3.0 \\
Fibrous dysplasia & 1 & -1 & 11 & 4.5 \\
Miscellaneous & 4 & 3 & 1 & 30 to 45 & 2.0 to 5.0 \\
\hline
\end{tabular}

T/B, target-to-background

Table II. Details of 10 operations for excision of osteoid osteoma in which the cadmium telluride probe was used

\begin{tabular}{|c|c|c|c|c|c|c|}
\hline Site & $\begin{array}{l}\text { Number } \\
\text { of cases }\end{array}$ & $\begin{array}{l}\text { Sex } \\
\text { M }\end{array}$ & $\mathbf{F}$ & $\begin{array}{l}\text { Age } \\
\text { (years) }\end{array}$ & $\begin{array}{l}T / B \\
\text { ratio }\end{array}$ & Comments \\
\hline Femoral neck & 3 & 3 & - & 11 to 33 & 2.5 to 4.0 & Good results \\
\hline Femoral shaft & 1 & 1 & - & 23 & 2.5 & $\begin{array}{l}\text { Re-exploration } \\
\text { after previous } \\
\text { attempt at } \\
\text { removal-good } \\
\text { result }\end{array}$ \\
\hline Tibia & 3 & 2 & 1 & 3 to 15 & 4.0 to 8.0 & Good results \\
\hline Scaphoid & 1 & - & 1 & 25 & 3.0 & $\begin{array}{l}\text { Good result at } \\
\text { one year }\end{array}$ \\
\hline Talus & 1 & - & 1 & 21 & 12.0 & Good result \\
\hline Patella & 1 & - & 1 & 6 & 2.5 & Good result \\
\hline
\end{tabular}




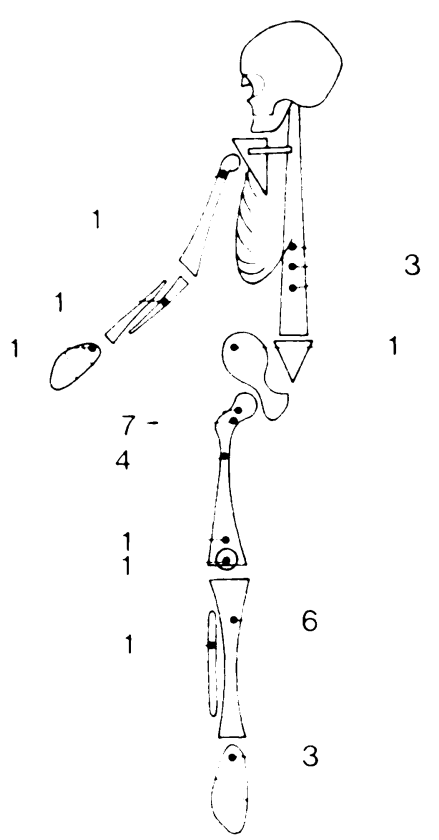

Fig. 2

The distribution of the 30 osteoid osteomas reported.

Table III. Details of 20 operations for osteoid osteoma in which the sodium iodide probe was used

\begin{tabular}{lllllll}
\hline Site & $\begin{array}{l}\text { Number } \\
\text { of cases }\end{array}$ & $\begin{array}{l}\text { Sex } \\
\mathbf{M}\end{array}$ & $\mathbf{F}$ & $\begin{array}{l}\text { Age } \\
\text { (years) }\end{array}$ & $\begin{array}{l}\text { T/B } \\
\text { ratio }\end{array}$ & Comments \\
\hline Femoral neck & 4 & 3 & 1 & 7 to 14 & 1.3 to 1.6 & $\begin{array}{l}\text { Failure in } \\
\text { three: two } \\
\text { due to back- } \\
\text { ground from } \\
\text { bladder; one } \\
\text { to a cable } \\
\text { fault }\end{array}$ \\
\end{tabular}

\begin{tabular}{|c|c|c|c|c|c|c|}
\hline Femoral shaft & 4 & 2 & 2 & 7 to 12 & 1.5 to 2.0 & $\begin{array}{l}\text { In one case } \\
\text { the amount } \\
\text { resected was } \\
\text { not reduced } \\
\text { by the probe }\end{array}$ \\
\hline Ilium & 1 & - & 1 & 17 & 1.2 & \\
\hline Tibial shaft & 3 & 2 & 1 & 18 to 26 & 1.3 to 1.5 & $\begin{array}{l}\text { One failure } \\
\text { due to cable } \\
\text { fault }\end{array}$ \\
\hline Fibula & 1 & 1 & - & 11 & 1.7 & \\
\hline Talus & 2 & 2 & - & 8 and 16 & 2.5 and 4.0 & \\
\hline Ulna & 1 & 1 & - & 24 & 4.0 & \\
\hline Humerus & 1 & - & 1 & 18 & 4.5 & \\
\hline Spine & 3 & 3 & - & 11 to 18 & 1.3 to 4.0 & $\begin{array}{l}\text { One recurred } \\
\text { at } 10 \text { months; } \\
\text { initially low } \\
T / B \text { ratio }\end{array}$ \\
\hline
\end{tabular}

VOL. 68-B, NO. 4, AUGUST 1986
RESULTS

The cadmium telluride probe was used successfully at the time of operation in 20 patients to locate abnormal tissue. The manoeuvrability and directional characteristics of the probe proved especially useful when the lesion lay deep in bone. There was no equipment failure and the target-to-background ratio was always greater than 2.0 (Table I).

To date we have used either the sodium iodide or the cadmium telluride probe to locate 30 histologically proven osteoid osteomas (Fig. 2); the calcium telluride probe was used in 10 patients (Table II). In all cases the probe was successful in locating the lesion and helping to ensure complete excision. The target-to-background ratio was always greater than 2.5. Follow-up from three months to two years has revealed no recurrence of symptoms.

The sodium iodide probe was used in 20 cases (Table III) with five failures: two due to deterioration of the fibre-optic cable, two due to high background readings caused by radioactivity in the bladder near hip lesions and one when the surgeon thought the probe had been of little use in reducing the amount of bone resection. In only five cases $(25 \%)$ were the target-tobackground ratios greater than 2.5 . In all 20 patients, the immediate postoperative recovery was satisfactory with only one recurrence to date. This followed removal of a $6 \mathrm{~mm}$ block of bone from the pars interarticularis of T11 vertebra. The target-to-background ratio was only 1.3 but scanning at operation suggested that removal of the tumour had been complete. Symptoms settled after operation but returned 10 months later; subsequent radionuclide imaging showed increased uptake at the level of attempted tumour resection.

In general, the target-to-background ratios were lower when measured with the sodium iodide probe than those obtained with the cadmium telluride detector (Fig. 3). The Mann-Whitney $U$ test showed the difference in sensitivities between the two probes to be statistically significant at $\mathrm{p}<0.001$.

\section{DISCUSSION}

The cadmium telluride system with a $20 \%$ energy window was approximately 10 times more sensitive to the $140 \mathrm{keV}$ radiation emitted by technetium- $99 \mathrm{~m}$ than the sodium iodide detector described previously (Colton and Hardy 1983), with improved target-to-background ratios being obtained during operations. The cadmium telluride detector has also proved more reliable mainly because of the elimination of the fibre-optic light guide and the energy losses inherent in such a system (Harvey and Lancaster 1981).

Osteoid osteoma has proved an ideal lesion on which to validate the intra-operative bone scanning technique, since it is often difficult to visualise on standard radiographs but invariably concentrates the 
bone-imaging radiopharmaceuticals. The probe can be used at operation to locate other bone lesions which have

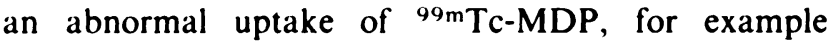
discrete metastatic deposits. It has also been useful to differentiate between living and dead bone during operations for chronic bone infection.

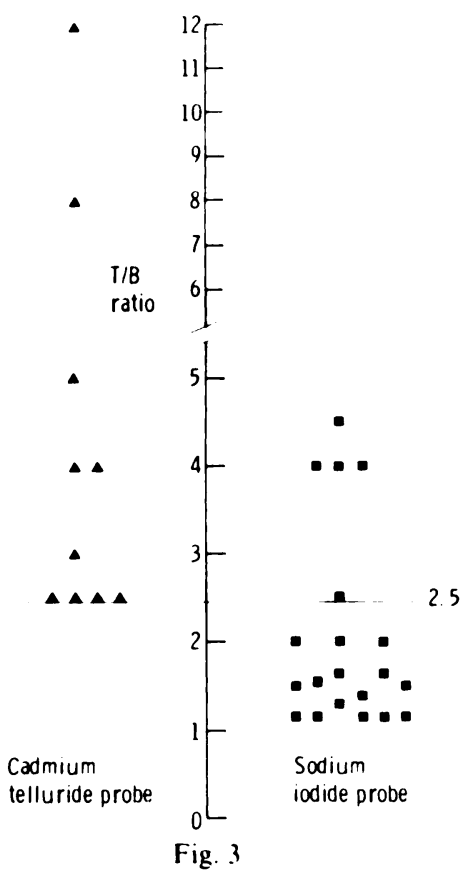

The target-to-background $(T / B)$ ratios recorded using the cadmium telluride and the sodium iodide probes.

More importantly, the calcium telluride probe can be used to detect any of the radiopharmaceuticals used for gamma-camera imaging. Two examples of this are the localisation of a retrosternal parathyroid adenoma using [ ${ }^{201} \mathrm{~T} 1$ ] thallous chloride (Ubhi, Hardy and Pegg 1984) and the intra-operative localisation of a softtissue abscess which concentrated gallium-67 (Harvey and Lancaster 1981). Antibodies radiolabelled with indium-111 or iodine isotopes are being used increasingly for tumour detection (Farrands et al. 1982, 1983) and probe detectors may have a role during biopsy of such tumours.

Conclusions. Scintigraphy can be used at operation to locate lesions which concentrate gamma-emitting radiopharmaceuticals. A cadmium telluride probe detector has proved more reliable and sensitive than the sodium iodide probe, since it does not require a fibre-optic cable.
These probes are particularly useful to localise an osteoid osteoma during excision biopsy, helping both to identify the lesion and to ensure its complete excision.

Our thanks are due to the many surgeons who have co-operated in the trial and especially to Mrs A. Stanton for her patient secretarial assistance.

\section{REFERENCFS}

Broderick T, Resnick D, Usselman J. Case report 123 : osteoid osteoma of the tibia with removal confirmed on specimen tomography. Skeletal Radiol 1980:5:193-5.

Clark CR, Ozonoff MB, Drennan JC. Case report 157. Skeletal Radiol $1981: 6: 2869$.

Colton CL, Hardy JG. Evaluation of a sterilizable radiation probe as an aid to the surgical treatment of osteoid osteoma : technical note. $J$ Bone Joint Surg [Am] 1983:65 A:1019-22.

Dunlop JAY, Morton KS, Elliott GB. Recurrent osteoid osteoma: report of a case with a review of the literature. J Bone Joint Surg $[B r] 1970 ; 52$ B: 128-33.

Duthie RB, Bentley G. Mercer's orthopaedic surgery. 8th ed. London: Edward Arnold, 1983

Farrands PA, Perkins AC, Pimm MV, et al. Radioimmunodetection of human colorectal cancers by an anti-tumour monoclonal antibody. Lancet 1982:ii:397 400 .

Farrands PA, Perkins A, Sully L, et al. Localisation of human osteosarcoma by antitumour monoclal antibody. J Bone Joint Surg $[B r] 1983: 65 \quad$ B :638 40

Gamba JL, Apple JS, Martinez S. Current concepts in the radiographic evaluation of osteoid osteoma. Ret Interam Radiol 1983:8:53-8.

Gamba JL, Martinez S, Apple J, Harrelson JM, Nunley JA. Computed tomography of axial skeletal osteoid osteomas. AJR 1984:142:769 72 .

Glynn JJ, Lichtenstein L. Osteoid-osteoma with multicentric nidus: a report of two cases. J Bone Joint Surg [Am] 1973:55-A :855-8.

Golding JSR. The natural history of osteoid osteoma: with a report of twenty cases. J Bone Joint Surg [Br] 1954;36- B:218 29.

Harvey WC, Lancaster JL. Technical and clinical characteristics of a surgical biopsy probe. J Nucl Med 1981:22:184-6.

Jackson RP, Reckling FW, Mantz FA. Osteoid osteoma and osteoblastoma: similar histologic lesions with different natural histories. Clin Orthop 1977:128:303-13.

Jaffe HL. "Osteoid-osteoma": a benign osteoblastic tumor composed of osteoid and atypical bone. Arch Surg 1935:31:709 28.

Lisbona R, Rosenthall L. Role of radionuclide imaging in osteoid osteoma. AJR 1979;132:77-80.

Mallens WM, Pauwels EK, Tetteroo QF. Bone scintigraphy as a guide to the diagnosis of osteoid osteoma. Radiol Clin (Basel) 1977:46:300 6 .

Rinsky LA, Goris M,Bleck EE, Halpern A, Hirshman P. Intraoperative skeletal scintigraphy for localization of osteoid-osteoma in the spine: case report. J Bone Joint Surg [Am] 1980;62-A :143-4.

Smith FW, Gilday DL. Scintigraphic appearances of osteoid osteoma. Radiology 1980:137:191 5.

Subramanian G, McAfee JG. A new complex of ${ }^{99 \mathrm{~m}} \mathrm{Tc}$ for skeletal imaging. Radiology 1971:99:192 6 .

Swee RG, McLeod RA, Beabout JW. Osteoid osteoma: detection, diagnosis and localization. Radiology 1979:130:117-23.

Ubhi CS, Hardy JG, Pegg CAS. Mediastinal parathyroid adenoma : a new method of localization. Br J Surg 1984:71:859 60. 